\title{
An Evaluation of Implementation of Quality Management System ISO 9001:2008 on Contractor for Six Senses Uluwatu Villa Resort Bali Project
}

\author{
Dewa Ketut Sudarsana, Putu Ari Sanjaya, Made Mahat Budhi Adnyana \\ Civil Enginering Department, Faculty of Engineering, Udayana University, Bali, Indonesia
}

Email address:

dksudarsana@unud.ac.id (D.K. Sudarsana),arisanjayaputu@yahoo.com(P.A. Sanjaya),mahatbudhi@gmail.com(M. M. B. Adnyana)

\section{To cite this article:}

Dewa Ketut Sudarsana, Putu Ari Sanjaya, Made Mahat Budhi Adnyana. An Evaluation of Implementation of Quality Management System ISO 9001:2008 on Contractor for Six Senses Uluwatu Villa Resort Bali Project. International Journal of Engineering Management.

Vol. 2, No. 1, 2018, pp. 8-14. doi: 10.11648/j.ijem.20180201.12

Received: February 22, 2018; Accepted: March 8, 2018; Published: April 8, 2018

\begin{abstract}
The project quality management system is a necessary process to ensure that the project would be executed has guaranteed quality system according to expectations and needs. An evaluation of quality management systems of ISO 9001:2008 series studied on contractor in Indonesia. As case study on PT Hutama Karya contractor for Six Senses Uluwatu Villa Resort Bali project. The execution was achieved by using a research instrument in the form of a checklist. A factor that becomes an obstacle in the implementation was obtained through observation, interview and verify documents of related staff. Assessment of the implementation of ISO 9001:2008 are clause 4, clause 5, clause 6, clause 7, and clause 8 is obtained by qualitative descriptive statistical analysis method, using audit score methods developed with rating measurement scale. Data analysis results can be categorized as very good with the percentage of $93.13 \%$. The implementation level of the 4th clause, quality management system of $90.00 \%$ included in the category is very good. The implementation level of the 6th clause, management of resources of $91.76 \%$ is included in the very good category. The implementation level of the 7 th clause, product realization of $93.33 \%$ is included in the very good category. The implementation level of the 8th clause i.g. measurement, analysis and improvement of $94.00 \%$ is categorized as very good. The 5 th clause becomes the element that gets the highest score with the percentage of $96.25 \%$. The 4 th clause becomes the element with the lowest value with a percentage of $90.00 \%$. Implementation has not reached $100 \%$ due to labor factor. Labor factor results in the emergence of another constraint factor such as documentation.
\end{abstract}

Keywords: Evaluation, Implementation, ISO 9001:2008, Obstacles, Contractor, Villa Project

\section{Introduction}

A company is established to continue to grow and develop over the times and the number of competitors that exist. In global markets, companies must be able to demand what is required by the market. When the market response to a company is high, it can survive in a global market economy. This is indicated by the high level of customer satisfaction with the use of products and Services Company [3]. For construction companies, to improve customer satisfaction can be applied quality management system that provides added value for the company.

The project quality management system is a necessary process to ensure that the project will produce quality assured according to the expectations and needs [4]. In implementing the quality management system standardization is required thoroughly. Standardization in the quality management system includes control and quality assurance to achieve the planned quality management system. A standardized quality management system is an ISO-based quality management system. One type of ISO that is developing currently is ISO 9001: 2008 which regulates the quality management system and has been recognized nationally and internationally.

In Indonesia, the current implementation of quality management system based on ISO 9001: 2008 becomes the main priority in construction service activities. This is because the implementation of ISO-based quality management system has become the Ministry of Public Works policy set since 2001. The objective of the policy is to seek and realize the quality of construction products 
according to the expectations and needs of consumers. Although the ISO 9001: 2008 quality management system seeks the quality of products to meet consumer expectations and needs, ISO 9001: 2008 is not a product standard, but a system standard because it does not state the requirements to be met by the product [1], [11].

PT Hutama Karya is a business entity in Indonesia engaged in construction and has been certified ISO 9001: 2008 since 2014 and ended in 2017. Therefore, it is important to examine how the implementation level of ISO 9001: 2008 quality management system. And what factors become obstacles in the implementation of quality management system in one of the projects being done by PT. Hutama Karya. The project to be studied is the Six Senses Uluwatu Villa Resort Bali project.

\section{Literature Review}

\subsection{Quality Management System}

Quality is a conformity of a product that satisfies the requirements and compliance with the use.

The quality management system is a set of documented procedures and standard practices for system management aimed at ensuring conformity of a process to specific needs and requirements. These requirements or requirements are defined or specified and customized by customers and organizations [2].

\subsection{ISO 9001:2008}

ISO (International Organization for Standardization) is a world standard body established to promote international trade related to goods and services. ISO is an international organization responsible for the preparation of new standards or revisions of existing ISO standards [6], [8], [10]. ISO 9001: 2008 is not a product standard, but a system standard. In this case ISO 9001: 2008 is only a quality management system so that companies implementing and obtaining ISO certificates can state that their quality management system meets international standards, not international standard products. ISO 9001: 2008 consists of clause 1 concerning the scope, clause 2 concerning normative reference, clause 3 concerning terms and definitions, clause 4 concerning the quality management system, clause 5 on management responsibilities, clause 6 concerning resource management, clause 7 concerning realization product, and clause 8 on measurement, analysis, and improvement.

\subsection{Clause of ISO 9001:2008}

As for each clause of ISO 9001: 2008 as follows [6], [9], [11]:

a. Clause 1: Scope.

In this clause, it emphasizes to meet customer satisfaction, including processes for continuous improvement and conformity assurance.

b. Clause 2: Normative Reference.

This clause only contains references (Government
Regulations, both central and local government and quality guidebooks) that must be prepared by the company to implement the ISO 9001: 2008 quality management system.

c. Clause 3: Terms and Definitions.

This clause contains the terms and definitions required to apply the quality management system.

d. Clause 4: Quality Management System.

This clause states that the organization's management must establish, document, and implement, and improve the quality management system.

e. Clause 5: Management Responsibility.

This clause emphasizes the commitment of top management (top management commitment). The organization's management must commit to the development and improvement of ISO 9001: 2008 quality management system.

f. Clause 6: Resource Management.

The organization shall provide the necessary resources to implement and maintain the ISO 9001: 2008 quality management system.

g. Clause 7: Product Realization.

The organization shall ensure that the product realization process is under control, in order to meet product requirements.

h. Clause 8: Measurement, Analysis and Enhancement. The organization shall establish plans and implement the processes of measurement, monitoring, analysis and improvement necessary to ensure the suitability of the products, ensuring the suitability of the quality management system and improving the continuous improvement of the quality management system.

\section{Research Methodology}

Research instrument in the form of checklist filled with writer during research in the project. To know the level of implementation of ISO 9001: 2008 quality management system that refers to the implementation in the project. The checklist used as an instrument contains a list of process descriptions referred to in clause 4 , clause 5 , clause 6 , clause 7 , and clause 8 of ISO 9001: 2008. Moreover, process descriptions refer to the literature, company manuals and related studies.

\subsection{Determination of Respondents}

Determination of informants in this study was taken by using purposive sampling method, where this method serves to select informants who have quality, capability or strength (credible) in order to obtain accurate data. The credible informant he referred to here refer to three levels of management. Three levels of management consist of the top level of management, middle level of management, first line management. However, this study only uses informants from middle-level management and first-line management, because top management has been given full authority to middle management to be responsible for all activities in the project, but top management is still doing inspection to know 
the progress and constraints experienced project.

\subsection{Data Collection}

Data collection used primary data and secondary data. Primary data include the results of project checklists and interviews to obtain constraints in the implementation of the quality management system. The collection of checklist results and interviews of implementation constraints were made to personnel who were considered credible in their respective fields to answer the description of ISO 9001: 2008 checklist on Six Senses Uluwatu Villa Resort Bali project. The selected informants included project manager, deputy project manager, procurement, site administration manager, site operation manager, site engineer manager, and system and quality controller. Assessment of checklist by using a series of descriptions of ISO 9001: 2008 quality management system process. The process descriptions of clauses 4 to clause 8 of ISO 9001: 2008. The description contained in the checklist is explained in more detail and adapted to the application in the project so that the informant can more easily understand the purpose of the process description and the resource person can provide the appropriate answer. Resource answers obtained are given a score on the checklist sheet. Scoring through interviews is also supported by validation of documentation in accordance with the process described in order to give the scores relevant to the implementation in the project. The scoring on the checklist is performed only by circling (0) in the appropriate column against each of the assessed characteristics. Data collection to get the factors that become obstacles in the implementation of quality management system is done by interviewing on every description of a process that get score less good (score 1, score 2, and score 3). Secondary data used include ISO 9001: 2008 quality management system standard, company manual and documentation of quality management system in the project.

\subsection{Data Analysis}

Data analysis used qualitative descriptive statistical analysis. The data collected in the form of quantitative data because the informant will not answer one of the qualitative answers (bad, bad, moderate, good, very good), but answer one of the quantitative answers $(1,2,3,4$, or 5$)$ is available on the checklist. The quantitative data obtained in the form of checklist scoring is further interpreted in the qualitative sense by using a rating scale. Excess rating scale, which is easy in the assessment process because the data in the form of quantitative data. Rater only circles (O) in the corresponding value column of each of the assessed variables. Assessment on checklist refers to the assessment criteria and is transformed into Table 1.

The criteria for assessment of ISO 9001: 2008 checklist is as follows:

a. Score 1: Very Bad (no quality management system (QMS); no documentation; no implementation).

b. Score 2: Bad (QMS available; but no documentation; not implemented in the project).

c. Score 3: Medium (QMS available, but not organized; documentation available, but not organized; that is implemented in the project)

d. Score 4: Good (QMS available; documentation available and organized; that is implemented, but not done in full on project, less or equal to $80 \%$ )

e. Score 5: Very Good (QMS available; documentation is available and organized; that is fully implemented or applied more than $80 \%$ )

Table 1. Table of Scoring Assessment Criteria.

\begin{tabular}{llllll}
\hline Score & $\mathbf{1}$ & $\mathbf{2}$ & $\mathbf{3}$ & $\mathbf{4}$ & \\
\hline Quality management system & $\mathrm{X}$ & $\sqrt{ }$ & $\sqrt{\text { Disorganized }}$ & $\sqrt{ }$ & \\
Documentation & $\mathrm{X}$ & $\mathrm{X}$ & $\sqrt{ }$ Not distributed & $\sqrt{ }$ \\
Implementation & $\mathrm{X}$ & $\mathrm{X}$ & $\sqrt{ }$ & $\sqrt{ } \leq 80 \%$ & $\sqrt{ }$ \\
\hline
\end{tabular}

The rating category in the rating scale is as follows and is clarified in Figure 1 (Sugiyono, 2009):

1) Very Bad $(B R S)=(0 \leq$ Score $<20 \%)$

2) $\mathrm{Bad}(\mathrm{BR})=(20 \% \leq$ Score $<40 \%)$

3) Medium $(S)=(40 \% \leq$ Score $<60 \%)$

4) $\operatorname{Good}(\mathrm{B})=(60 \% \leq$ Score $<80 \%)$

5) Very Good $(\mathrm{SB})=(80 \% \leq$ Score $\leq 100 \%)$

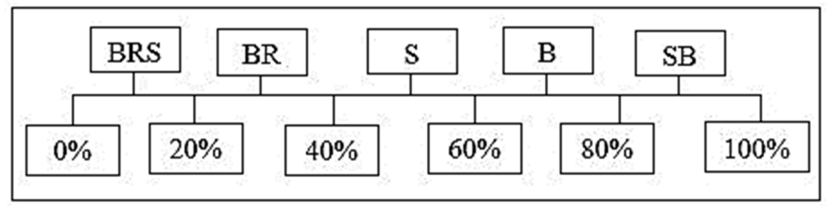

Figure 1. Ratings Category in Scale.

Qualitative descriptive statistical data analysis is used to describe the data in the form of scoring results that have been collected so as to provide a clear picture of the implementation of the implementation in general. The result of the tabulated checklist score, then calculated each clause and calculated the level of implementation of the quality management system as a whole by using the following formula [5]:

$$
\text { Score }=\frac{\text { Total score }}{\text { The highest score }} \times 100 \%
$$

Explanation

Total Score $=$ Total Value of each Clause checklist

\section{Results}

\subsection{General Description of the Company}

Companies at the research sites have met quality standards in terms of quality, safety and environment with ISO 9001: 2008, OHSAS 18001: 2007, and ISO 14001: 2004 certified. ISO 9001: 2008 certification was obtained from SGS United Kingdom Ltd with validity from March 25, 2014 to March 25, 2017. 


\subsection{Implementation of Quality Management System ISO 9001: 2008}

Assessment of the implementation level of ISO 9001: 2008 quality management system through clause 4, clause 5, clause 6 , clause 7 , and clause 8 . The level of implementation of the quality management system that has been applied can be determined by calculating the percentage of applications of each clause. The results of the implementation of each clause are tabulated into the table and calculated the total implementation score, then divided by the maximum score that can be obtained if the implementation is done as a whole $(100 \%)$

\subsection{Clause 4. Quality Management System}

The number of statements in clause 4 is 22 process descriptions. The result of the recapitulation description process of checklist clause 4 ISO 9001: 2008 at Six Senses Uluwatu Villa Resort Project are 11 elements with score 5 and 11 with the score 4 . Recapitulation results obtained for each score are tabulated to facilitate data processing. Tabulation of data is shown in Table 2.

Table 2. Tabulation clause 4

\begin{tabular}{|c|c|c|c|c|c|c|c|c|c|c|c|c|}
\hline \multirow{3}{*}{$\begin{array}{l}\text { Clause } \\
\text { ISO }\end{array}$} & \multirow{3}{*}{ Total question } & \multicolumn{11}{|c|}{ Tabulation results } \\
\hline & & \multirow{2}{*}{$\sum \mathbf{S B}$} & \multirow{2}{*}{ b x 5} & \multirow{2}{*}{$\sum \mathbf{B}$} & \multirow{2}{*}{ d x 4} & \multirow{2}{*}{$\sum \mathbf{S}$} & \multirow{2}{*}{ f $x 3$} & \multirow{2}{*}{$\sum \mathbf{B S}$} & \multirow{2}{*}{ h $x 2$} & \multirow{2}{*}{$\sum$ BRS } & \multirow{2}{*}{ j $\mathbf{x} 1$} & $\mathbf{c}+\mathbf{e}$ \\
\hline & & & & & & & & & & & & $+g+i+k$ \\
\hline 9001:2008 & $\mathbf{a}$ & b & c & d & e & f & g & $\mathbf{h}$ & i & $\mathbf{j}$ & $\mathbf{k}$ & $\mathbf{L}$ \\
\hline 4 & 22 & 11 & 55 & 11 & 44 & 0 & 0 & 0 & 0 & 0 & 0 & 99 \\
\hline
\end{tabular}

The percentage of implementation of clause 4 ISO 9001: 2008 can be calculated in the following ways:

a. Looking for the highest score

The number of clause 4 in the checklist is 22 , so the total score is: $22 \times 5=110$.

b. Total score in project

Based on the results of the tabulation checklist of the project, obtained the total score for clause 4 that is 99 .

c. The level of implementation of clause 4 is calculated in the following way:

$$
\begin{aligned}
\text { Score } & =\frac{\text { Total score }}{\text { The highest score }} \times 100 \% \\
= & \frac{99}{100} \times 100 \%=99.00 \%
\end{aligned}
$$

The result obtained clause 4 ISO 9001: 2008 PT. Hutama Karya at Uluwatu Villa Resort Bali Six Senses Project is $90.00 \%$. The results are included in the rating scale that includes in the "very good" category.

\subsection{Clause 5. Management Responsibility}

The number of statements in clause 5 is 16 process descriptions. The result of the recapitulation description of the process of checklist clause 5 ISO 9001: 2008 on Six Senses Uluwatu Villa Resort Project are: 13 elements with score 5 and 3 with the score 4 . Recapitulation results obtained for each score are tabulated to facilitate data processing. Tabulation of data is presented in Table 3.

\begin{tabular}{|c|c|c|c|c|c|c|c|c|c|c|c|c|}
\hline Clause & \multirow[b]{2}{*}{ Total question } & \multicolumn{11}{|c|}{ Tabulation results } \\
\hline ISO & & $\sum \mathbf{S B}$ & b $\times 5$ & $\sum \mathbf{B}$ & d $x 4$ & $\sum \mathbf{S}$ & f $\times 3$ & $\sum$ BS & h $\times 2$ & $\sum$ BRS & i $\times 1$ & $c+e$ \\
\hline 9001:2008 & $\mathbf{a}$ & b & c & d & e & f & g & h & $\mathbf{i}$ & i & $\mathbf{k}$ & $\frac{+\mathbf{g}+\mathbf{i}+\mathbf{k}}{\mathrm{L}}$ \\
\hline 5 & 16 & 13 & 65 & 3 & 12 & 0 & 0 & 0 & 0 & 0 & 0 & 77 \\
\hline
\end{tabular}

Table 3. Tabulation clause 5

The percentage of implementation of clause 5 ISO 9001: 2008 can be calculated in the following ways:

a. Looking for the highest score

The number of clause 5 in the checklist is 16 , so the total score is: $16 \times 5=80$.

b. Total score of the project

Based on the results of the tabulation checklist of the project, obtained the total score for clause 5 that is 77 .

c. The level of implementation of clause 5 is calculated in the following way:

$$
\text { Score }=96.25 \%
$$

The result obtained clause 5 ISO 9001: 2008 PT. Hutama Karya at Uluwatu Villa Resort Bali Six Senses Project is
$96.25 \%$. The results are included in the rating scale that includes in the "very good" category.

\subsection{Clause 6. Management Responsibility}

The number of statements in clause 6 is 17 process descriptions. The result of the recapitulation description process of checklist clause 6 ISO 9001: 2008 at Six Senses Uluwatu Villa Resort Project are 10 elements with score 5 and 7 with the score 4 . Recapitulation results obtained for each score are tabulated to facilitate data processing. Tabulation of data is presented in Table 4 . 
Table 4. Tabulation clause 6.

\begin{tabular}{|c|c|c|c|c|c|c|c|c|c|c|c|c|}
\hline \multirow{3}{*}{$\begin{array}{l}\text { Clause } \\
\text { ISO }\end{array}$} & \multirow{3}{*}{ Total question } & \multicolumn{11}{|c|}{ Tabulation results } \\
\hline & & \multirow{2}{*}{$\sum \mathbf{S B}$} & \multirow{2}{*}{ b x 5} & \multirow{2}{*}{$\sum \mathbf{B}$} & \multirow{2}{*}{ d $x 4$} & \multirow{2}{*}{$\sum \mathbf{S}$} & \multirow{2}{*}{$f \times 3$} & \multirow{2}{*}{$\sum \mathbf{B S}$} & \multirow{2}{*}{ h $\times 2$} & \multirow{2}{*}{$\sum \mathbf{B R S}$} & \multirow{2}{*}{ j $\mathbf{x} 1$} & $\mathbf{c}+\mathbf{e}$ \\
\hline & & & & & & & & & & & & $+\mathbf{g}+\mathbf{i}+\mathbf{k}$ \\
\hline 9001:2008 & $\mathbf{a}$ & b & c & d & e & f & g & h & $\mathbf{i}$ & $\mathbf{j}$ & $\mathbf{k}$ & $\mathbf{L}$ \\
\hline 6 & 17 & 10 & 50 & 7 & 28 & 0 & 0 & 0 & 0 & 0 & 0 & 78 \\
\hline
\end{tabular}

The percentage of implementation of clause 6 ISO 9001: 2008 can be calculated in the following ways:

a. Looking for the highest score

The number of clause 6 in the checklist is 17 , so the total score is: $17 \times 5=85$.

b. Total score in project

Based on the results of the tabulation checklist of the project, obtained the total score for clause 6 that is 78 .

c. The level of implementation of clause 6 is calculated in the following way:

Score $=91.76 \%$

The result obtained clause 6, ISO 9001: 2008 PT. Hutama Karya at Uluwatu Villa Resort Bali Six Senses Project is
$91.76 \%$. The results are included in the rating scale that includes in the "very good" category.

\subsection{Clouse 7. Product Realization}

The number of statements in clause 7 is 48 process descriptions. The result of the recapitulation description process of checklist clause 7 ISO 9001: 2008 at Six Senses Uluwatu Villa Resort Project are 33 elements with score 5 and 14 with the score 4

Recapitulation results obtained for each score are tabulated to facilitate data processing. Tabulation of data is presented in Table 5.

Table 5. Tabulation clause 7.

\begin{tabular}{|c|c|c|c|c|c|c|c|c|c|c|c|c|}
\hline \multirow{3}{*}{$\begin{array}{l}\text { Clause } \\
\text { ISO }\end{array}$} & \multirow{3}{*}{ Total question } & \multicolumn{11}{|c|}{ Tabulation results } \\
\hline & & \multirow{2}{*}{$\sum \mathbf{S B}$} & \multirow{2}{*}{ b x 5} & \multirow{2}{*}{$\sum \mathbf{B}$} & \multirow{2}{*}{ d x 4} & \multirow{2}{*}{$\sum \mathbf{S}$} & \multirow{2}{*}{ f $x 3$} & \multirow{2}{*}{$\sum \mathbf{B S}$} & \multirow{2}{*}{ h $x 2$} & \multirow{2}{*}{$\sum \mathbf{B R S}$} & \multirow{2}{*}{ j $\mathbf{x} 1$} & $\mathbf{c}+\mathbf{e}$ \\
\hline & & & & & & & & & & & & $+\mathbf{g}+\mathbf{i}+\mathbf{k}$ \\
\hline 9001:2008 & $\mathbf{a}$ & $\mathbf{b}$ & c & d & e & f & g & $\mathbf{h}$ & i & $\mathbf{j}$ & $\mathbf{k}$ & $\mathbf{L}$ \\
\hline 7 & 48 & 33 & 165 & 14 & 56 & 1 & 3 & 0 & 0 & 0 & 0 & 224 \\
\hline
\end{tabular}

The percentage of implementation of clause 7 ISO 9001: 2008 can be calculated in the following ways:

a. Looking for the highest score

The number of clause 7 in the checklist is 48 , so the total score is: $48 \times 5=240$.

b. Total score in project

Based on the results of the tabulation checklist of the project, obtained the total score for clause 7 that is 224 .

c. The level of implementation of clause 7 is calculated in the following way:

Score $=93.33 \%$

The result obtained clause 7 ISO 9001: 2008 PT. Hutama Karya at Uluwatu Villa Resort Bali Six Senses Project is
$93.33 \%$. The results are included in the rating scale that includes in the "very good" category.

\subsection{Clause 8. Measurement, Analysis and Improvement}

The number of statements in clause 8 , are 28 process descriptions. The recapitulation of the description of the process of checklist clause 8, ISO 9001: 2008 on Six Senses Uluwatu Villa Resort are 20 elements with score 5 and 8 with the score 8 . Recapitulation results obtained for each score are tabulated to facilitate data processing. Tabulation of data is presented in Table 6.

Table 6. Tabulation clause 8 .

\begin{tabular}{|c|c|c|c|c|c|c|c|c|c|c|c|c|}
\hline Clause & \multirow{3}{*}{ Total question } & \multicolumn{11}{|c|}{ Tabulation results } \\
\hline \multirow{2}{*}{ ISO } & & \multirow{2}{*}{$\sum$ SB } & \multirow{2}{*}{ b x 5} & \multirow{2}{*}{$\sum \mathbf{B}$} & \multirow{2}{*}{ d $x 4$} & \multirow{2}{*}{$\sum \mathbf{S}$} & \multirow{2}{*}{ f $x 3$} & \multirow{2}{*}{$\sum$ BS } & \multirow{2}{*}{ h $\times 2$} & \multirow{2}{*}{$\sum \mathrm{BRS}$} & \multirow{2}{*}{ j $\mathbf{x} 1$} & $\mathbf{c}+\mathbf{e}$ \\
\hline & & & & & & & & & & & & $+\mathbf{g}+\mathbf{i}+\mathbf{k}$ \\
\hline 9001:2008 & $\mathbf{a}$ & b & $\mathbf{c}$ & d & e & $\mathbf{f}$ & g & h & $\mathbf{i}$ & $\mathbf{j}$ & $\mathbf{k}$ & $\mathbf{L}$ \\
\hline 8 & 28 & 20 & 100 & 8 & 32 & 0 & 0 & 0 & 0 & 0 & 0 & 132 \\
\hline
\end{tabular}

The percentage of implementation of clause 8 ISO 9001: 2008 can be calculated in the following ways:

a. Looking for the highest score

The number of clause 8 in the checklist is 28 , so the total score is: $28 \times 5=140$.

b. Total score in project

Based on the results of the tabulation checklist of the project, obtained the total score for clause 8 that is 132 . c. The level of implementation of clause 8 is calculated in the following way:

Score $=94.29 \%$

The result obtained clause 8 ISO 9001: 2008 PT. Hutama Karya at Uluwatu Villa Resort Bali Six Senses Project is $94.29 \%$. The results are included in the rating scale that includes in the "very good" category. 


\subsection{Implementation of Quality Management System ISO 9001: 2008}

Level implementation of quality management system ISO 9001: 2008 PT. Hutama Karya on Six Senses Uluwatu Villa
Resort Bali project is obtained from the calculation of the percentage of implementation of each clause. The percentages of each clause are tabulated in Table 7 and illustrated in Figure 2.

Table 7. Recapitulation percentage of implementation clause 4 to clause 8 of ISO 9001: 2008.

\begin{tabular}{llll}
\hline No & Clause & Implementation & Category \\
\hline 1 & 4 (Quality management system) & $90,00 \%$ & SB \\
2 & 5 (Management Responsibility) & $96,25 \%$ & SB \\
3 & 6 (Resource Management) & $91,76 \%$ & SB \\
4 & 7 (Product Realization) & $93,33 \%$ & SB \\
5 & 8 (Measurement, Analysis and Improvement) & $94,29 \%$ & SB \\
\hline
\end{tabular}

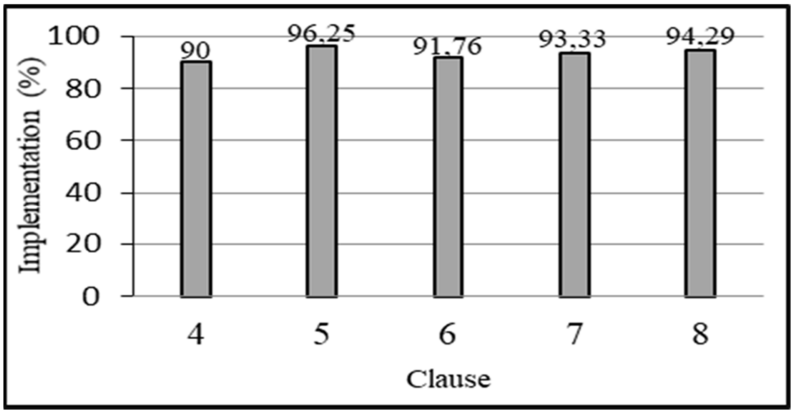

Figure 2. Graph Percentage of Implementation Clause 4 to Clause 8 ISO 9001: 2008
Based on Table 7 and Figure 7 that the entire implementation of ISO 9001: 2008 from clauses 4 to clause 8 on Six Senses Uluwatu Villa Resort project included in the category very good, clause 5 (management responsibility) became the clause that obtained the highest score with a percentage of $96,25 \%$. Clause 4 (quality management system) becomes the clause with the lowest value with a percentage of $90.00 \%$.

Level implementation of quality management system ISO 9001: 2008 PT. Hutama Karya on Six Senses Uluwatu Villa Resort Bali Project can be calculated referring to Table 8 .

Table 8. Tabulation of clause 4 to clause 8.

\begin{tabular}{|c|c|c|c|c|c|c|c|c|c|c|c|c|}
\hline \multirow{3}{*}{$\begin{array}{l}\text { Clause } \\
\text { ISO }\end{array}$} & \multirow{3}{*}{ Number of statements } & \multicolumn{11}{|c|}{ Tabulation Results } \\
\hline & & \multirow{2}{*}{$\sum \mathbf{S B}$} & \multirow{2}{*}{ b x 5} & \multirow{2}{*}{$\sum \mathbf{B}$} & \multirow{2}{*}{ d $x 4$} & \multirow{2}{*}{$\sum \mathbf{S}$} & \multirow{2}{*}{$f \times 3$} & \multirow{2}{*}{$\sum \mathbf{B S}$} & \multirow{2}{*}{ h $\times 2$} & \multirow{2}{*}{$\sum$ BRS } & \multirow{2}{*}{ j $\mathbf{x} 1$} & \multirow{2}{*}{$\begin{array}{l}\mathbf{c}+\mathbf{e} \\
+\mathbf{g}+\mathrm{i}+\mathrm{k}\end{array}$} \\
\hline & & & & & & & & & & & & \\
\hline 9001:2008 & $\mathbf{a}$ & b & c & d & e & f & g & h & i & $\mathbf{j}$ & $\mathbf{k}$ & I \\
\hline 4 & 22 & 11 & 55 & 11 & 44 & 0 & 0 & 0 & 0 & 0 & 0 & 99 \\
\hline 5 & 16 & 13 & 65 & 3 & 12 & 0 & 0 & 0 & 0 & 0 & 0 & 77 \\
\hline 6 & 17 & 10 & 50 & 7 & 28 & 0 & 0 & 0 & 0 & 0 & 0 & 78 \\
\hline 8 & 28 & 20 & 100 & 8 & 32 & 0 & 0 & 0 & 0 & 0 & 0 & 132 \\
\hline Result & 131 & 87 & 435 & 43 & 172 & 1 & 3 & 0 & 0 & 0 & 0 & 610 \\
\hline
\end{tabular}

Calculate the implementation level of ISO 9001: 2008 quality management system.

a) Looking for the highest score

The number of clauses in the process of clause 4 to clause 8 in the checklist is 131 , the total score is: $131 \mathrm{x}$ $5=655$.

b) Total score of the project

Based on the results of the tabulation checklist in the field, obtained the total value of tabulation clause 4 to clause 8 that is 604 .

c) The level implementation of clause 4 to clause 8 is calculated:

Score $=93.13 \%$

The final result of implementation level is $93.13 \%$. These results fall into the "Very Good" category shown in Figure 3.

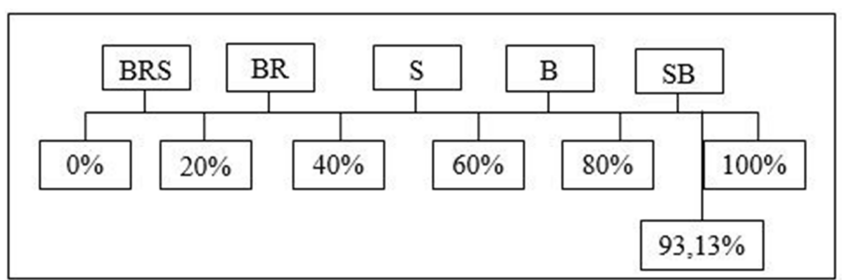

Figure 3. Level of implementation of ISO 9001: 2008 in rating scale.

\subsection{Obstacles Implementation of Quality Management System ISO 9001: 2008}

Implementation of ISO 9001: 2008 quality management system on Six Senses Uluwatu Villa Resort project undertaken by PT. Hutama Karya has not achieved maximum results. The lack of implementation of the ISO 9001: 2008 quality management system is due to the constraints. The constraint factor in the implementation lies in clause 7 for the 
description of the manpower, making schedule process by the site operation manager. The constraint factor of this process description is labor and documentation. Schedule man power is not planned from the beginning to the end of the project, but is revised every week after the weekly meeting is completed. This schedule is made in accordance with the progress of the project. The daily manpower schedule documentation used is only recorded using paper sheets and reported using the gadget application. Manpower reporting using the application is more effective and efficient, but documentation is not in accordance with the requirements.

\section{Conclusion}

The result of analysis of ISO 9001: 2008 quality management system implementation of construction project with case study of Six Senses Uluwatu Villa Resort Bali project, it can be concluded that, level of implementation of quality management system ISO 9001: 2008 PT Hutama Karya on Six Senses Uluwatu Villa Resort Bali project is $93.13 \%$ and can be categorized very good $(<80 \%$ until $100 \%$ ). The implementation level of the 4 th clause (quality management system) of $90.00 \%$ included in the category is very good. The implementation level of the 5th clause (management responsibility) of $96.25 \%$ included in the category is the very good. The implementation level of the 6th clause (management of resources) of $91.76 \%$ is included in the very good category. The implementation level of the 7 th clause (product realization) of $93.33 \%$ is included in the very good category. The implementation level of the 8th clause (measurement, analysis and improvement) of $94.29 \%$ is categorized as very good. The 5 th clause becomes the element that gets the highest score with the percentage of $96.25 \%$. The 4th clause becomes the element with the lowest value with a percentage of $90.00 \%$. There some factors that become obstacles in the implementation of ISO 9001: 2008 quality management system are the factors of manpower (HR) and implementation of documentation. Labor (HR) becomes the dominant factor as obstacles in the implementation and documentation that become obstacles implementation of quality management system caused by labor factor. Lack of awareness of labor to record or record in accordance with procedures or in accordance with the requirements of ISO 9001: 2008. Moreover, there are some activities that have not been documented in the project as evidence of conformity that the applicable requirements in ISO 9001: 2008 are actually implemented on the Six Senses Uluwatu Villa Resort Bali project.

\section{References}

[1] Anonimus. 2008. Sistem Manajemen Mutu - Persyaratan SNI ISO 9001: 2008. Badan Standarisasi Nasional.

[2] Gaspersz, V. 2006. ISO 9001:2000 and Continual Quality Improvement, Jakarta: PT. Gramedia Pustaka Utama.

[3] Mulia, T. G. M. 2011. Implementasi Sistem Manajemen Mutu ISO 9001:2008 pada Perusahaan Jasa Konstruksi. (Tugas Akhir yang tidak dipublikasikan, Jurusan Teknik Sipil Fakultas Teknik Universitas Atma Jaya Yogyakarta 2011).

[4] Pamulu, M. S. 2005. Studi Implementasi ISO 9000: 2000 pada Perusahaan Konstruksi di Makassar, Jurnal Teknik Sipil. Vol. 12, No. 3 Juli 2005.

[5] Putra, I. G. N. N. A. 2015. Implementasi Sistem Manajemen Mutu ISO 9001:2008 PT Waskita Karya pada Proyek Pembangunan Gedung Blok E RSUD Kabupaten Badung. (Tugas Akhir yang tidak dipublikasikan, Jurusan Teknik Sipil Fakultas Teknik Universitas Udayana 2015).

[6] Suardi, R. 2003. Sistem Manajemen Mutu ISO 9000:2000, PPM, Jakarta.

[7] Sugiyono, 2009. Metode Penelitian Kuantitatif, Kualitatif, dan $R \& D$, Bandung: Alfabeta

[8] Pangemanan, D.G.G., Tarore, H.2013. Faktor-Faktor Yang Mempengaruhi Efektifitas Penerapan Manjemen Mutu ISO 9001:2008 Pada Perusahaan Kontraktordi Kota Manado. Jurnal Ilmiah Media Engineering Vol. 3, No. 1, Maret 2013, ISSN 2087-9334 pages: 49-53.

[9] Santosa, M.A.W., Widhiawati, I.A.R., Gede Astawa Diputra G.A. 2013. Penerapan Standar Sistem Manajemen Mutu (ISO) 9001:2008 Pada Kontraktor PT. Tunas Jaya Sanur. Jurnal Ilmiah Elektronik Infrastruktur Teknik Sipil, Volume 2, No. 1, Pebruari 2013.

[10] Thilakarathne, P.M.C., Chithrangani S. K. C. 2014. A Study on Analysis of Managerial Attitudes towards ISO 9001: 2008 Quality Management System Introduction and Implementation Process in Sri Lanka. International Journal of Economics, Finance and Management Sciences, Volume 2, Issue 2, April 2014, Pages: 123-131

[11] Artha, P.G.B., Adnyana, I. B.R., Widhiawati I.A.R., 2013. Implementasi Sistem Manajemen MISO 9001:2008 pada proyek Alaya Resort Ubud. Jurnal Ilmiah Elektronik Infrastruktur Teknik Sipil, Volume 2, No. 1, Pebruari 2013. 